\title{
PŘEPRAVNÍ SMLOUVY V MEZINÁRODNÍ MULTIMODÁLNÍ PřEPRAVĚ A ROTTERDAMSKÁ PRAVIDLA
}

\section{CONTRACTS FOR INTERNATIONAL MULTIMODAL CARRIAGE AND ROTTERDAM RULES}

Radek Novák1,*

\begin{abstract}
Abstrakt Dosud neexistuje žádná platná nadnárodní (mezistátní) právní úprava přepravní smlouvy v multimodální, resp. intermodální přepravě. Platné mnohostranné mezinárodní úmluvy o přepravní smlouvě v současnosti řeší pouze jednotlivé dopravní módy. OSN, resp. UNCITRAL, vytvořila Rotterdamská pravidla (Úmluvu OSN o smlouvě o mezinárodní přepravě zboží zcela nebo z části po moři), která zatím nejsou ratifikována potřebným počtem států, aby mohla vstoupit v platnost. Setkávající se však také s kritikou. V článku jsou předložena základní fakta o této problematice $s$ akcentem na analýzu současného stavu dopravního práva z pohledu České republiky.
\end{abstract}

Klíčová slova Rotterdamská pravidla, mezinárodní nákladní přeprava, intermodální přeprava, odpovědnost nákladního dopravce.

Summary There is no valid international (interstate) legal regulation of the contract of carriage in multimodal or intermodal transport. The current multilateral international conventions on the contract of carriage deal with individual modes of transport only. The United Nations (UN), or UNCITRAL as their agency, has elaborated the Rotterdam Rules (UN Convention on Contracts for the International Carriage of Goods Wholly or Partly by Sea) that have not been ratified by the required number of countries to enter into force yet. Moreover, it also met with criticism. The article highlights the key elements of the issue emphasizing the analysis of the current state of transport law perspective in the Czech Republic.

Keywords Rotterdam Rules, international freight transport, intermodal transport, liability of the freight carrier.

\section{1 ÚVOD}

Na úrovni mnohostranných mezinárodních úmluv o přepravní smlouvě, které upravují práva a povinnosti smluvních stran (dopravce a odesílatele), zatím chybí platná nadnárodní (mezistátní) právní úprava pro multimodální, resp. intermodální přepravu. V současnosti jsou přepravní smlouvy v mezinárodní

\footnotetext{
${ }^{1}$ Vysoká škola ekonomická v Praze, Fakulta podnikohospodářská, Katedra logistiky, nám. W. Churchilla 1938/4, 13067 Praha 3 - Žižkov, ČR

${ }^{*}$ korespondenční autor, tel.: +420 602805 907, e-mail: radek.novak@vse.cz
} 
multimodální přepravě upravovány jednotlivými mnohostrannými úmluvami (dohodami) obsahujícími právní úpravu těchto vztahů pouze v rámci jednotlivých dopravních módů (Poláček, 2017). Tyto mnohostranné mezinárodní úmluvy je pak třeba použít v kontextu jednotlivých dopravních módů tak, jak byly tyto dopravní módy v konkrétním praktickém př́ípadě využity. V ČR, stejně tak, jako v jiných tzv. členských státech mnohostranných mezinárodních úmluv, jsou tyto začleněny do národního práva, což je podstatou a strategickým smyslem jejich existence.

Určitým východiskem z této relativně komplikované situace by však eventuálně mohla být Rotterdamská pravidla, která již byla vytvořena na půdě OSN. Charakteristiku současného stavu, ale i pohled na přednosti a nedostatky Rotterdamských pravidel, se snaží obsáhnout tento článek.

Autorovi článku není známo, že by se v předkládaném kontextu a pojetí této problematice někdo věnoval, resp. že by byl tento problémový okruh byl v daném kontextu řešen či zpracován. Proto také vznikl tento článek.

\section{SOUČASNÝ STAV ÚPRAVY PŘEPRAVNÍ SMLOUVY V MEZINÁRODNÍ NÁKLADNÍ PŘEPRAVĚ}

Jak bylo výše uvedeno, přepravní smlouvy v mezinárodní multimodální přepravě v současnosti vycházejí z mnohostranných mezinárodních úmluv upravující přepravní smlouvu v jednotlivých dopravních módech.

Těmito mnohostrannými úmluvami o přepravní smlouvě v jednotlivých dopravních módech jsou:

- silniční doprava:

○ Úmluva CMR 1956

- Železniční doprava:

- $\operatorname{COTIF}(\mathrm{CIM}) 1980$

- námořní doprava:

○ Haagská pravidla 1924

○ Haagsko - Visbyská pravidla 1968

○ Hamburská pravidla 1978

- letecká doprava:

○ Varšavská úmluva (1929-1999)

○ Montrealská úmluva (1999 a později)

- vnitrozemská plavba:

○ Úmluva CMNI 2001 (platnost jen pro Evropu).

\subsection{Integrace mnohostranných mezinárodních úmluv upravujících přepravní smlouvu do národního práva ČR}

V legislativních podmínkách ČR jsou mnohostranné mezinárodní úmluvy o přepravní smlouvě v nákladní přepravě v současnosti reprezentovány těmito právními předpisy:

- Vyhláškou ministra zahraničních věcí č. 11/1975 Sb., o Úmluvě o přepravní smlouvě v mezinárodní silniční nákladní dopravě (CMR), ve znění sdělení Ministerstva zahraničních věcí č. 108/2006 Sb. m. s. (Úmluva CMR)

- Přípojkem B (CIM) vyhlášky ministra zahraničních věcí č. 8/1985 Sb., o Úmluvě o mezinárodní železniční přepravě (COTIF), ve znění sdělení federálního ministerstva zahraničních věcí č. 61/1991 Sb., sdělením federálního ministerstva zahraničních věcí č. 251/1991 Sb., sdělením Ministerstva zahraničních věcí č. 274/1996 Sb., sdělením Ministerstva zahraničních věcí č. 60/1999 Sb., sdělením Ministerstva zahraničních věcí č. 9/2002 Sb. m. s., sdělením Ministerstva zahraničních věcí č. 46/2003 Sb. m. s., sdělením Ministerstva zahraničních věcí č. 8/2004 Sb. m. s., 
sdělením Ministerstva zahraničních věcí č. 34/2005 Sb. m. s., sdělením Ministerstva zahraničních věcí č. 19/2007 Sb. m. s., sdělením Ministerstva zahraničních věcí č. 19/2011 Sb. m. s. a sdělením Ministerstva zahraničních věcí č. 65/2016 Sb. m. s. (Úmluva CIM)

- Sdělením Ministerstva zahraničních věcí č. 193/1996 Sb., o přijetí Úmluvy Organizace spojených národů o námořní přepravě zboží (Hamburská pravidla)

- Sdělením Ministerstva zahraničních věcí č. 123/2003 Sb. m. s., o přijetí Úmluvy o sjednocení některých pravidel o mezinárodní letecké přepravě (Montrealská úmluva)

- Sdělením Ministerstva zahraničních věcí č. 32/2006 Sb. m. s., o sjednání Budapešt’ské úmluvy o smlouvě o přepravě zboží po vnitrozemských vodních cestách (Úmluva CMNI).

\section{MULTIMODÁLNÍ PŘEPRAVNÍ PODMÍNKY}

V souladu s multimodálními přepravními podmínkami, které se opírají o pravidla UNCTAD/ICC, UNCTAD - Konference OSN pro obchod a rozvoj (United Nations Conference on Trade and Development), ICC - Mezinárodní obchodní komora (International Chamber of Commerce), byl organizací FIATA, Mezinárodní federace zasilatelských svazů (Fédération Internationale des Associations de Transitaires et Assimilés) vydán vzor multimodálního konosamentu označeného FIATA FBL. Jedná se o převoditelný multimodální konosament (Negotiable FIATA Multimodal Transport Bill of Lading). Vystavovat takový dokument může pouze oprávněný zasílatel po náležitém splnění podmínek vyhlášených federací FIATA. FIATA FBL (nebo jen FBL) je plnohodnotným obchodovatelným dokumentem a plní funkci cenného papíru. Taktéž BIMCO, Baltská a mezinárodní námořní rada (Baltic and International Maritime Council), vydalo podle pravidel UNCTAD/ICC Uniform Rules for Multimodal Transport Documents vzor multimodálního konosament - Multimodal Transport Bill of Lading, MULTIDOC 95 (BIMCO, 2016). Multimodální konosament má řadu vlastností společných s námořním konosamentem. Nepotvrzuje však dodání na palubu lodi, ale pouze skutečnost, že zboží bylo dodáno do kontejnerového terminálu. Je cenným obchodovatelným papírem a kryje přepravu po moři i dále, až do konečného místa určení (Poláček a Novák 2019). Na podkladě pravidel UNCTAD/ICC vydala rejdařská organizace BIMCO rovněž svůj vzorový dokument. Jde o námořní nákladní list označený pod názvem Multimodal Transport Waybill (MULTIWAYBILL 95). Ten je však pouze dokumentem dispozičním a bývá vystavován jako námořní nákladní list s funkcí legitimačního dokumentu (Kolář, 2017). Taktéž FIATA vydala pravidla pro vystavování multimodálního nákladního listu FIATA FWB (Non-negotiable FIATA Multimodal Transport Waybill), který má charakter nepřevoditelného multimodálního nákladního listu (Poláček a Novák 2019).

Velmi zásadním je, že ani pravidla UNCTAD/ICC, FIATA či BIMCO nemají charakter mnohostranné mezinárodní úmluvy, která by mohla být podkladem pro závaznou právní úpravu v rámci národního práva, ale jsou jen tzv. doporučeními, byt’ s různou měrou jejich celosvětového rozšíření.

\section{ROTTERDAMSKÁ PRAVIDLA}

Rotterdamská pravidla - celým názvem Úmluva OSN o smlouvě o mezinárodní přepravě zboží zcela nebo z části po moři (United Nations Convention on Contracts for the International Carriage of Goods Wholly or Partly by Sea) byla vypracována UNCITRAL, Komise OSN pro mezinárodní obchodní právo (United Nations Commission on International Trade Law).

\subsection{Charakteristika obsahu Rotterdamských pravidel}

Rotterdamská pravidla se do značné míry snaží nahradit dosud neexistující mezinárodní mnohostrannou úmluvu o přepravní smlouvě v mezinárodní multimodální, resp. intermodální přepravě (tzn. v přepravě s využitím několika módů dopravy, kdy však zásilka zůstává v jedné přepravní jednotce - nejčastěji v kontejneru). Jejich cílem je tedy nahradit především Hamburská pravidla a další obdobné, resp. související, mezinárodní mnohostranné úmluvy o přepravní smlouvě. 
Zásadní odlišností od mezinárodních mnohostranných úmluv o přepravní smlouvě upravujících dosud tyto vztahy pouze v jednom dopravním módu je, že Rotterdamská pravidla zahrnují úpravu přepravních vztahů nejen v námořní přepravě, ale také v předcházející (Precarriage) a návazné (Oncarriage) přepravě. $V$ tomto ohledu tedy zohledňují fakt, že dosud neexistuje žádná mnohostranná mezinárodní úmluva upravující problematiku přepravní smlouvy v multimodální, resp. intermodální přepravě.

V případě, že by se však námořní přeprava prováděla jen jako doplněk k přepravě silniční, železniční, letecké či vnitrozemské vodní, pak by se ustanovení Rotterdamských pravidel neaplikovala. Tato situace je ale v praxi samo sebou velmi málo pravděpodobná.

Rotterdamská pravidla obsahují ohledně námořní přepravy ustanovení, že jejich smluvní stát nemůže být zároveň smluvním státem Haagských nebo Hamburských pravidel. V př́ípadě, že je některý stát členským státem některých z výše uvedených Pravidel, a chtěl by přistoupit k Rotterdamským pravidlům, byl by povinen starší Pravidla vypovědět. Rozdíly mezi Haagskými a Hamburskými pravidly jsou především v postupném prosazování zájmů odesílatelů nad zájmy námořních rejdařủ (dopravců). To je vidět napřr. na zvyšování limitů odpovědnosti rejdařů za ztrátu, zničení nebo poškození zásilky (Haagská pravidla 2,0 SDR/kg hrubé hmotnosti, Hamburská pravidla 2,5 SDR/kg hrubé hmotnosti a Rotterdamská pravidla 3,0 SDR/kg hrubé hmotnosti). Jak je v tomto článku na několik místech zmíněno, Rotterdamská pravidla pokrývají navíc intermodální přepravu, resp. smlouvu o mezinárodní přepravě zboží zcela nebo z části po moři, zatímco Haagská a Hamburská pravidla tuto problematiku řeší výhradně v rámci námořní přepravy.

Rotterdamskými pravidly by se měly řídit přepravní smlouvy v mezinárodní námořní, ale zároveň také související nákladní přepravě (tzn. např. i v navazující mezinárodní silniční nákladní dopravě), pokud by místo přijetí zásilky k přepravě a místo jejího dodání bylo ve dvou různých státech a pokud by ve dvou různých státech ležel i přístav nakládky a přístav vykládky. To vše by platilo za předpokladu, že by se alespoň místo přijetí zásilky, místo jeho dodání, přístav jejího nalodění nebo přístav jejího vylodění nacházel ve smluvním státě Rotterdamských pravidel.

Text obsahující ustanovení Rotterdamských pravidel je možno co do svého rozsahu označit za značně obsáhlý (obsahuje 96 článků). Rotterdamská pravidla se snaží uvedenou problematiku řešit velmi komplexně a relativně velmi podrobně. Např. již v prvních jejich ustanoveních vymezují a definují všechny pojmy, které by se mohly při jejich výkladu později ukázat jako problémové.

\subsection{Proces přijetí a problémy Rotterdamských pravidel}

Rotterdamská pravidla byla připravována UNCITRAL na řadě mezivládních jednání, která trvala více než 10 let (Van Steemderen MainportLawyers, 2014).

V textu Rotterdamských pravidel je zakotveno, že proto, aby se tato stala účinná, je třeba, aby je ratifikovalo alespoň 20 ze členských států OSN.

Rotterdamská pravidla dosud podepsalo 25 států, ale ratifikovalo je pouze 5 států (Španělsko, Togo, Demokratické Kongo, Kamerun a Benin) (United Nations Commission On International Trade Law, 2019).

Následně, co by Rotterdamská pravidla potřebný počet ratifikací získala, byla by závazná jen pro jejich smluvní státy. Tzn., že by ale nadále stále existovala řada států, které by i nadále v oblasti námořních přepravních smluv aplikovaly Haagská nebo Hamburská pravidla, a pro ostatní dopravní módy ustanovení stávajících mnohostranných úmluv o přepravní smlouvě.

Právě v tomto faktu je jeden z velmi vážných problémů, protože právě tím by totiž bezesporu došlo k roztř̌ištění mezinárodní právní úpravy v oblasti přepravních vztahů zahrnujících přepravní smlouvu v námořní přepravě. $V$ námořní přepravě jsou v této oblasti celosvětově používána Haagská (Úmluva 1924), Haagsko-Visbyská (Protokol 1968) a Hamburská pravidla (Úmluva 1978). 
Hodnocení významu Rotterdamských pravidel je rozporuplné. Na jedné straně vznik Rotterdamských pravidel uvítaly některé svazy rejdařů - Svaz majitelů námořních plavidel Evropského společenství, Mezinárodní komora námořní plavby - ICS, Baltská a mezinárodní námořní rada - BIMCO a Světová rada námořní plavby - WSC (Van Steemderen MainportLawyers, 2014).

Existuje však i mnoho kritiků, kteří Rotterdamským pravidlům především vyčítají nejen jejich poměrně velký rozsah, ale především možnost jejich různých interpretací.

Lze se domnívat, že právě jejich značná složitost patrně povede nejen k nejasnostem při jejich společném jednotném výkladu, ale vzhledem $k$ rozdílné rozhodovací praxi soudů $v$ různých státech světa může vést i ke vzniku zbytečných sporů.

Ze stanovisek mezinárodních organizací sdružujících zasílatele (event. zasílatelské národní svazy), lze uvést názory:

FIATA - Mezinárodní federace zasílatelských svazů (Fédération Internationale des Associations de Transitaires et Assimilés) - považuje Rotterdamská pravidla za „př́liš komplikovaná“ (Van Steemderen MainportLawyers, 2014).

CLECAT - Celoevropský spediční svaz (European Association for Forwarding, Transport, Logistics and Customs services) - označil je za „extrémně komplikovaná a obtížně srozumitelná (Van Steemderen MainportLawyers, 2014).

Svaz spedice a logistiky ČR (SSL ČR) - jako řádný člen FIATA, který reprezentuje zájmy zasílatelských firem ČR-se k Rotterdamským pravidlům vyjadřuje vesměs negativně, i když připouští, že objektivně přinášejí i některé dílčí pozitivní aspekty (dle názorů předsedy a výkonného ředitele Svazu).

Nemalé výhrady byly směřovány na konkrétní ustanovení Rotterdamských pravidel týkající se možnosti uzavírání množstevních kontraktů (Volume Contracts) - přepravních smluv pro větší objem zboží přepraveného během určité doby. Tyto smlouvy jsou totiž z platnosti nových pravidel prakticky vyňaty (údajně ale odborníci odhadují, že právě ty mohou představovat až 90 \% celosvětové kontejnerové přepravy).

\section{POROVNÁNÍ LIMITU゚ ODPOVĚDNOSTI DOPRAVCE S ROTTERDAMSKÝMI PRAVIDLY}

Jednou z nejvýznamnějších částí mezinárodních mnohostranných úmluv o přepravní smlouvě jsou v nich stanovené limity odpovědnosti dopravce. Stejně, jako ostatní ustanovení těchto úmluv, mají i tyto limity kogentní charakter a lze se jim vyhnout pouze v př́padě aplikace kogentních postupů v těchto úmluvách přesně stanovených (např. aplikací ustanovení článků 24 nebo 26 Úmluvy CMR).

Odpovědnost dopravce je v mezinárodních mnohostranných úmluvách uváděna v členských státech MMF - Mezinárodního měnového fondu (International Monetary Found - IMF) pomocí jednotné fiktivní měnové jednotky - tzv. Zvláštních práv čerpání (ZPČ), resp. Special Driving Rights (SDR/XDR). Přepočet limitované odpovědnosti dopravce v konkrétním dopravním módu se provádí tak, že se vynásobí hrubá hmotnost zásilky (tj. včetně jejího obalu) určená v kilogramech - která byla ztracena, zničena či poškozena - s daným koeficientem charakteristickým pro konkrétní mezinárodní mnohostrannou úmluvu. Při přepočtu na konkrétní národní měnu se pak ještě takto vzniklý výsledek vynásobí aktuálním kurzem SDR, který je vyhlašován příslušnou národní bankou daného státu.

Procentuální poměry jednotlivých měn zastoupených v tzv. měnovém koši:

Do 30.9.2016:

- Americký dolar (USD): 41,9\% 
- $\quad$ EMU (EUR): $37,4 \%$

- Japonský jen (JPY): 9,4\%

- Britská libra (GBP): 11,3 \%

Od 1.10.2016:

- Americký dolar (USD): 41,73\%

- $\quad$ EMU (EUR): 30,93 \%

- Japonský jen (JPY): 8,33 \%

- Britská libra (GBP): 8,09\%

- Č́nské renminbi (CNY): 10,92\%.

Limitace odpovědnosti dopravce je proto i pro Rotterdamská pravidla jejich velmi významnou součástí. Stejně jako v Hamburských pravidlech je tato limitace konstruována na principu presumovaného zavinění. Dopravce je tedy odpovědný za ztrátu nebo poškození zboží, př́ípadně za zpoždění s jeho dodáním, pokud se žalobci (nejčastěji přepravci/odesilateli) podaří prokázat, že škoda vznikla v době, kdy měl dopravce zboží ve své péči (tj. mezi přijetím zboží k přepravě a jeho doručením).

Rotterdamská pravidla obsahují limitovanou odpovědnost dopravce omezenou na 875 ZPČ/SDR za přepravní jednotku (takový limit odpovědnosti dopravce některé mnohostranné mezinárodní úmluvy o přepravní smlouvě ale neznají - např. Úmluva CMR) nebo na 3 ZPČ/SDR za jeden kilogram hrubé hmotnosti ( $v$ Úmluvě CMR 8,33 ZPČ/SDR) podle toho, která částka je vyšší (Hamburská pravidla stanovují limity náhradové povinnosti rejdaře ve výši 835 ZPČ/SDR za přepravní jednotku a 2,5 ZPČ/SDR za 1 kg hrubé hmotnosti zboží).

Tab. 1 Porovnání limitu odpovědnosti mezinárodního dopravce za ztrátu, zničení a poškození zásilky; zdroj: Česká republika, 1975 a 2006; Česká republika, 1985; Česká republika, 1996; Česká republika, 2003; Česká republika, 2006.

\begin{tabular}{llr}
\hline Dopravní mód (mnohostranná úmluva) & Ztráta, zničení, poškození \\
\hline Silniční (Úmluva CMR) & {$[$ SDR/kg hrubé hmotnosti] } & $\mathbf{8 , 3 3}$ \\
Železniční (Úmluva CIM) & {$[$ SDR/kg hrubé hmotnosti] } & $\mathbf{1 7 , 0 0}$ \\
Námořní (Hamburská pravidla) & {$[$ SDR/kg hrubé hmotnosti] } & $\mathbf{2 , 5 0}$ \\
Letecká (Montrealská úmluva) & {$[$ SDR/kg hrubé hmotnosti] } & $\mathbf{2 2 , 0 0}$ \\
Vnitrozemská vodní (Úmluva CMNI) & {$[$ SDR/kg hrubé hmotnosti] } & $\mathbf{2 , 0 0}$ \\
\hline Rotterdamská pravidla & {$[$ SDR/kg hrubé hmotnosti] } & $\mathbf{3 , 0 0}$ \\
\hline
\end{tabular}

Tab. 2 Porovnání limitu odpovědnosti mezinárodního dopravce při pozdním dodání (zpoždění) zásilky; zdroj: Česká republika, 1975 a 2006; Česká republika, 1985; Česká republika, 1996; Česká republika, 2003; Česká republika, 2006.

\begin{tabular}{lr}
\hline Dopravní mód (mnohostranná úmluva) & Pozdní dodání \\
\hline Silniční (Úmluva CMR) & přepravné \\
Železniční (Úmluva CIM) & $\mathbf{4}$ x přepravné \\
Námořní (Hamburská pravidla) & $\mathbf{2 , 5}$ x přepravné \\
Letecká (Montrealská úmluva) & $\mathbf{2 2 ~ S D R / k g ~ z p o z ̌ d e ̌ n e ́ ~ z a ́ s i l k y ~}$ \\
Vnitrozemská vodní (Úmluva CMNI) & pŕepravné \\
\hline Rotterdamská pravidla & $\mathbf{2 , 5}$ x přepravné \\
\hline
\end{tabular}

Odpovědnost za škodu vzniklou z důvodů pozdního dodání (zpoždění) je u Rotterdamských pravidel omezena na dvou a půl násobek přepravného, což je stejné jako u Hamburských pravidel. 


\subsection{Základní charakteristiky odpovědnosti dopravce podle Rotterdamských pravidel}

Pro určení výše náhrady škody při ztrátě nebo poškození zboží je rozhodná hodnota zásilky v době a místě dodání (i zde se vychází z burzovní ceny, eventuálně z ceny tržní).

Co se týče zproštění se viny zde platí, že dopravce má možnost udání několika důvodů, při jejichž prokázání se odpovědnosti zcela nebo z části zprostí (např. zásah vyšší moci, válka, ozbrojený konflikt, požár na lodi, snaha zachránit život či majetek na moři apod.).

Dopravce nemá možnost dovolávat se limitů pro náhradu škody, pokud jím byla škoda způsobena úmyslně nebo z nedbalosti.

V Rotterdamských pravidlech jsou nová ustanovení o zbavení se odpovědnosti dopravce při uplatněním opatření $k$ zabránění škod na životním prostř̌edí či $v$ případě stávky jsou. $V$ takových př́padech může žalobce prokázat, že dopravcem prokázaná okolnost vznikla nebo k jejímu vzniku přispělo dopravcovo zavinění. Žalobce má možnost prokázat, že nehledě na některý z uvedených důvodů, byla pravděpodobně ztráta (nebo poškození zboží, případně jeho opožděné dodání) způsobena nedostatečnou způsobilostí lodi k plavbě či jejím nedostatečným personálním či technickým vybavením.

I v Rotterdamských pravidlech, má dopravce možnost si s odesílatelem za příplatek k přepravnému dohodnout vyšší odpovědnostní limity. Odesílatel má možnost rovněž deklarovat v přepravní smlouvě vyšší hodnotu zásilky (tj. obdobně jako např. v článcích 24 a 26 Úmluvy CMR).

\section{ZÁVĚR}

V uvedeném článku je řešena problematika přepravní smlouvy v mezinárodní multimodální přepravě. Bylo konstatováno, že na mnohostranné mezinárodní úrovni dosud absentuje jakákoli platná, resp. účinná závazná nadnárodní (mezistátní) právní úprava pro multimodální, resp. intermodální přepravu.

Do budoucna by mohlo být eventuálním východiskem používání Úmluvy OSN o smlouvě o mezinárodní přepravě zboží zcela nebo z části po moři - tzv. Rotterdamských pravidel. Jejich hodnocení je však kontroverzní. Patrně nejvýznamnějším problémem se jeví to, že by Rotterdamská pravidla byla po jejich eventuálním přijetí (ratifikaci minimálně 20 státy) závazná pouze pro jejich smluvní státy. To by způsobilo, že by nadále stále existovala řada států, v nichž by byla v námořní přepravě i nadále používána Haagská nebo Hamburská pravidla a pro přepravní smlouvy zahrnující další dopravní módy by byly aplikovány současné mnohostranné mezinárodní úmluvy. Jejich přehled včetně popisu jejich začlenění do národního práva ČR a porovnání odpovědnostních limitů dopravců rovněž obsahuje tento př́íspěvek.

\section{Seznam zkratek}

BIMCO - Baltská a mezinárodní námořní rada (Baltic and International Maritime Council)

CLECAT - Celoevropský spediční svaz (European Association for Forwarding, Transport, Logistics and Customs services)

FIATA - Mezinárodní federace zasílatelských svazů (Fédération Internationale des Associations de Transitaires et Assimilés)

FBL - FIATA multimodální náložný list (Negotiable FIATA Multimodal Transport Bill of Lading)

FW - nepřevoditelný multimodální nákladní list (Non-negotiable FIATA Multimodal Transport Waybill)

ICC - Mezinárodní obchodní komora (International Chamber of Commerce)

MMF - Mezinárodní měnový fond (International Monetary Found - IMF) 
Rotterdamská pravidla - Úmluva OSN o smlouvě o mezinárodní přepravě zboží zcela nebo z části po moři (UN Convention on Contracts for the International Carriage of Goods Wholly or Partly by Sea)

UNCITRAL - Komise OSN pro mezinárodní obchodní právo (UN Commission on International Trade Law)

UNCTAD - Konference OSN pro obchod a rozvoj (United Nations Commission on Trade and Development)

ZPČ - zvláštní práva čerpání (Special Driving Rights - SDR/XDR).

\section{Literatura}

BIMCO. (C) 2016 "MULTIDOC 95” Multimodal Transport Bill of Lading. [Online]. Dostupné z: https://www.bimco.org/contracts-and-clauses/bimco-contracts/multidoc-95 [cit.: 2021, 11. březen].

Česká republika. 1975 a 2006. Vyhláška ministra zahraničních věcí č. 11/1975 Sb., o Úmluvě o přepravní smlouvě v mezinárodní silniční nákladní dopravě (CMR), ve znění sdělení Ministerstva zahraničních věcí č. 108/2006 Sb. m. s. (Úmluva CMR).

Česká republika. 1985. Př́ípojek B (CIM) vyhlášky ministra zahraničních věcí č. 8/1985 Sb., o Úmluvě o mezinárodní železniční přepravě (COTIF), ve znění pozdějších sdělení. (Úmluva CIM).

Česká republika. 1996. Sdělení Ministerstva zahraničních věcí č. 193/1996 Sb., o přijetí Úmluvy Organizace spojených národů o námořní přepravě zboží (Hamburská pravidla).

Česká republika. 2003. Sdělení Ministerstva zahraničních věcí č. 123/2003 Sb. m. s., o přijetí Úmluvy o sjednocení některých pravidel o mezinárodní letecké přepravě (Montrealská úmluva).

Česká republika. 2006. Sdělení Ministerstva zahraničních věcí č. 32/2006 Sb. m. s., o sjednání Budapešt’ské úmluvy o smlouvě o přepravě zboží po vnitrozemských vodních cestách (Úmluva CMNI).

Kolár̆, P. 2017. Čtvrtá průmyslová revoluce: výzvy digitalizace v námořní přepravě. Perner's Contacts, 12 (3), s. 48-61.

Osobní diskuse autora se zástupci Svazu spedice a logistiky, sdružení ČESMAD - Bohemia a dopravních a zasílatelských firem.

Poláček, B., Novák, R. 2019. Mezinárodní přepravní doklady. Praha: Wolters Kluwer.

Poláček, B. 2017. Kapitoly z mezinárodního dopravního práva III (E. Silniční právo, F. Multimodální právo). Praha: Wolters Kluwer.

United Nations Commission On International Trade Law. (c) 2019. Status: United Nations Convention on Contracts for the International Carriage of Goods Wholly or Partly by Sea (New York, 2008) (the

"Rotterdam Rules"). [Online]. Dostupné z:

https://uncitral.un.org/en/texts/transportgoods/conventions/rotterdam rules/status [cit.: 2021, 9. březen].

Van Steemderen MainportLawyers. CC 2014. Rotterdam Rules. [Online]. Dostupné z:

https://www.rotterdamrules.com [cit.: 2021, 8. březen]. 